\title{
Simple spectrophotometric assay for measuring catalase activity in biological tissues
}

\author{
Mahmoud Hussein Hadwan(1)
}

\begin{abstract}
Background: The details of a precise, accurate, and sensitive spectrophotometric method for measuring catalase activity are presented here. The assay was established for biological samples and depends on the rapid formation of a stable and colored carbonato-cobaltate (III) complex. Samples exhibiting catalase activity are incubated with hydrogen peroxide solution for 2 min prior to rapid mixing of the incubation enzymatic reaction mixture with cobalt-bicarbonate reagent, which assesses non-reacting hydrogen peroxide. Catalase activity is always directly proportional to the rate of dissociation of hydrogen peroxide. Hydrogen peroxide acts to oxidize cobalt (II) to cobalt (III) in the presence of bicarbonate ions; this process ends with the production of a carbonato-cobaltate (III) complex ([CO $\left.\left.\left(\mathrm{CO}_{3}\right)_{3}\right] \mathrm{Co}\right)$. The formed end product has two maximum absorbance peaks: $440 \mathrm{~nm}$ and $640 \mathrm{~nm}$. The 440-nm peak has been utilized for assessing catalase activity.
\end{abstract}

Results: The catalase activity results of the current method for erythrocyte lysate homogenates were computationally identical to those of the dichromate method $(r=0.9950)$. The coefficient of variation was calculated to determine the imprecision of the current assay. The within-run and between-run results were 2.96 and 3.83\%, respectively.

Conclusion: This method is appropriate for analyzing bacteria, red blood cells and liver and kidney tissue homogenates.

Keywords: Catalase activity, Hydrogen peroxide, Carbonato-cobaltate (III) complex, Cobalt, Bicarbonate

\section{Background}

Catalase (EC 1.11.1.6) is an important enzyme that acts to dissociate hydrogen peroxide $\left(\mathrm{H}_{2} \mathrm{O}_{2}\right)$ into molecular oxygen $\left(\mathrm{O}_{2}\right)$ and water $\left(\mathrm{H}_{2} \mathrm{O}\right)$ [1]. Catalase has a molecular weight equal to $250 \mathrm{kDa}$ and consists of four hemoprotein groups [2]. Like other antioxidant enzymes, catalase is also present in plants and animal cells such erythrocytes, renal cells and hepatic cells $[1,3]$. Catalase is also produced by a wide spectrum of prokaryotic and eukaryotic organisms. It is an intracellular enzyme that has been discovered in most facultative anaerobes and all aerobic bacteria, but is not present in obligate anaerobes [4]. Catalase is the second most abundant enzymatic antioxidant (after superoxide dismutase), which attenuates the levels of reactive oxygen species that ubiquitously accompany pathological disorders

Correspondence: mahmoudhadwan@gmail.com

Chemistry Department College of Science, University of Babylon, Hilla City, Babylon Governorate P.O. 51002, Iraq such as aging, cataract, cancer, nutritional deficiency, atherosclerosis, and diabetes [5].

There has been substantial progress in the development of efficient methods for assessing catalase activity in the fields of clinical pathology, biotechnology, and applied microbiology because of the spread of microbial populations in a variety of foods [6-17]. Several of these methods have been reported.

The principally common method for measuring catalase activity is the UV spectrophotometric method, which depends on monitoring the change of $240 \mathrm{~nm}$ absorbance at high levels of hydrogen peroxide solution $(\geq 30 \mathrm{mM})$. High levels of hydrogen peroxide $\left(\mathrm{H}_{2} \mathrm{O}_{2}\right)$ immediately lead to inhibition of the catalase enzyme by altering its active site structure, although there is variation in the extent to which this occurs. Additionally, there is a need for a method for continuously assessing low catalase activity against a high background level of absorbance because many cellular constituents, such as nucleic acids and proteins, exhibit intense absorption at $240 \mathrm{~nm}$ [18]. 
Other methods of measuring catalase activity have been developed, including those involving iodometry [19] chemiluminescence [14], polarimetry [15], and monitoring the production of oxygen via an oxygen electrode [20] or a low-flow gas meter [21]. These methods are time-consuming and inappropriate for clinical application. Alternatively, catalase activity can be measured quantitatively by titration of the unreacted excess of hydrogen peroxide [22]. However, this method may be associated with difficulty in end-point determination [23].

This paper reports a simple assay for measuring catalase activity that includes the measurement of hydrogen peroxide spectrophotometrically. This method is free from the interference that results from the presence of amino acids, proteins, sugars, and fats in the studied sample.

\section{Results}

Cobalt-bicarbonate solution can act as a" stop bath" for reactions regulated by the catalase enzyme. Immediately after mixing the cobalt-bicarbonate reagent with the enzyme reaction solution, its content of cobalt (II) is oxidized to cobalt (III); any unreacted hydrogen peroxide resulting from the catalase activity will oxidize the cobalt (II) to cobalt (III) and then react with carbonate to produce a carbonato-cobaltate (III) complex $\left(\left[\mathrm{Co}\left(\mathrm{CO}_{3}\right)_{3}\right] \mathrm{Co}\right)$ (Fig. 1a), which has an intense olive green color. Catalase activity is always directly proportional to the rate of dissociation of hydrogen peroxide in the used samples. The decrease of color intensity can be used as an index to represent the increase catalase activity (Fig. 1b). The spectrum of the colored end product [carbonato-cobaltate (III) complex ([Co $\left.\left.\left.\left(\mathrm{CO}_{3}\right)_{3}\right] \mathrm{Co}\right)\right]$ was scanned from 200 to $700 \mathrm{~nm}$ and showed bands at 440 and $640 \mathrm{~nm}$. The 440-nm band was used for measuring catalase activity (Fig. 1c).

To examine the potential impacts of chemical interference that might change the catalase activity, nine chemicals suggested to interfere with this activity were prepared by mixing $1 \mathrm{ml}$ of catalase with known activity $(5 \mathrm{U} / \mathrm{ml}$ ) and $9 \mathrm{ml}$ of a specific interfering substance dissolved in phosphate buffer (50 mM, pH 7.4). The resulting catalase activity was calibrated using the dichromate method as explained by Sinha [7] and modified by Hadwan [8]. The final activity equaled $0.5 \mathrm{U} \cdot \mathrm{mL}^{-1}$. Table 1 shows the effects of various types of interference on the catalase assay.

The results obtained for each sample by the present assay were compared with those obtained by the dichromate method as described previously by Sinha [7] and modified by Hadwan [8]. Identical buffer, substrate, and sample were used in both procedures. The results of the current method showed good precision (Table 2) and good correlation with the dichromate-dependent assay (Table 3).

The accuracy of the current method was calculated by the recovery of activity of the catalase enzyme that had been added to the reaction solution. The catalase enzyme was purchased from HiMedia Laboratories (New Delhi, India, product code: TC037). It was prepared in $0.05 \mathrm{mM}$ phosphate buffer solution and calibrated using the dichromate method, as documented previously by Sinha [7] and modified by Hadwan [8]. The results are detailed in Table 4.

Conversion of hydrogen peroxide $\left(\mathrm{H}_{2} \mathrm{O}_{2}\right)$ to molecular oxygen and water $\left(\mathrm{H}_{2} \mathrm{O}\right)$ in a chemical reaction regulated by catalase was monitored by determining the absorbance of the carbonato-cobaltate (III) complex as a function of time (as shown in Fig. 2). An ideal reaction time of $120 \mathrm{~s}$ was selected in the present method because this corresponded to the time when the absorbance plateau was reached, reflecting optimal hydrogen peroxide dissociation by the activity of the catalase enzyme.

The dilution sensitivity for red blood cell homogenate was evaluated using a carbonato-cobaltate (III) complex method. The identified catalase activities (instrumental measured activity) were determined and plotted against the expected catalase activity at a series of dilutions of red blood cell homogenate (Fig. 3). Figure 3 reveals the good correlation between these variables $(r=0.9985)$.

The carbonato-cobaltate (III) complex method was utilized to measure the catalase activity of liver and kidney tissue homogenates (1:500 diluted homogenate). These tissues were normally shown to exhibit higher catalase activity than other tissues (Fig. 4).

The present method was applied to measure the catalase activity in bacteria. Two bacterial laboratory strains were used for this (Escherichia coli and Staphylococcus aureus were isolated and diagnosed by Hussein O.M. Al-Dahmoshi/Advanced Microbiology Lab, College of Science, University of Babylon, Iraq). Staphylococcus aureus was normally shown to exhibit higher catalase activity than Escherichia coli (Fig. 5).

\section{Discussion}

This paper describes a new method for assessing catalase activity in various biological samples. This method depends on the oxidation of cobalt (II) to cobalt (III) by hydrogen peroxide in the presence of bicarbonate solution to produce a carbonato-cobaltate (III) complex ([Co $\left.\left.\left(\mathrm{CO}_{3}\right)_{3}\right] \mathrm{Co}\right)$. The reaction was shown to be very stable in terms of the end product produced for samples of hydrogen peroxide, with no significant change in the absorbance at $440 \mathrm{~nm}$ being observed at room temperature until $5 \mathrm{~h}$. This result agrees with the results obtained by Masschelein et al. [24].

According to the results shown in Table 1, the presence of vitamins, amino acids, proteins, and antioxidants in biological fluids did not interfere with the currently proposed method of assessing catalase activity. The absence of interference in the current method is due to its dependence on 

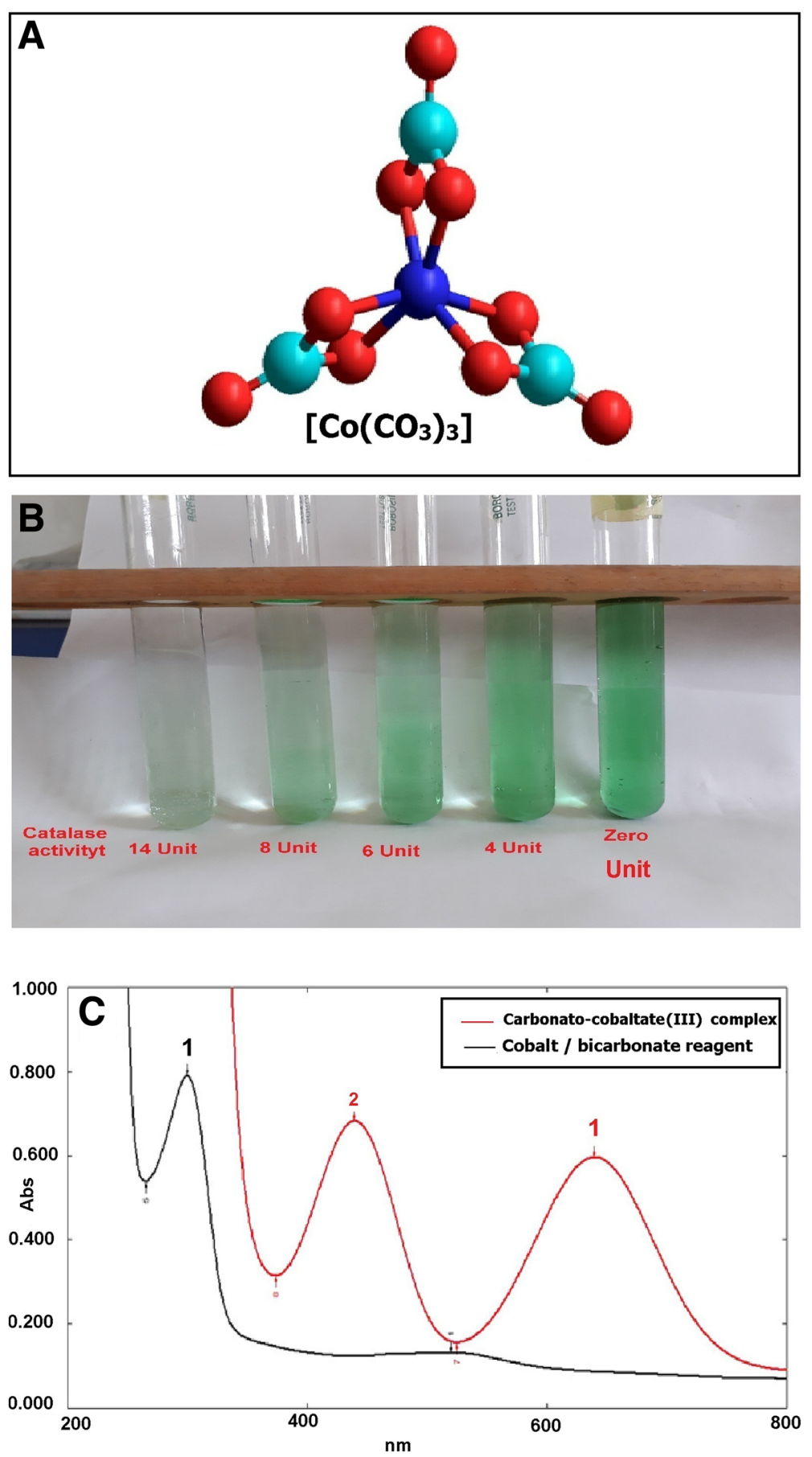

Fig. 1 The spectrophotometric properties of the carbonato-cobaltate(III) complex that correlates with the activity of catalase enzyme. a A carbonato-cobaltate(III) complex. b Decreased color intensity in association with increased catalase activity. c Absorption spectra obtained for the colorimetric products of the present assay

the basis of the oxidation property of the hydrogen peroxide on cobalt (II). When we consider that the concentration of oxidants in biological samples is very low compared with the hydrogen peroxide concentration used in catalase assessment methods (5-50 mM), this should explain the absence of interference.
The results of the high precision and accuracy of the current method as indicated in Tables 2 and 3 reveal the suitability of this method for clinical and research applications. The present assay is effective for measuring low concentrations of hydrogen peroxide (nontoxic and physiological concentrations), to which the frequently used 
Table 1 The effects of several interfering chemicals on the activity of the catalase enzyme

\begin{tabular}{lllll}
\hline Supposed chemical interferences & $\begin{array}{l}\text { Concentration of supposed } \\
\text { chemical interferences }\end{array}$ & Added catalase $\mathrm{U} \mathrm{mL}^{-1}$ & Found catalase $\mathrm{U} \mathrm{mL}^{-1}$ & Relative error (\%) $^{-1.8}$ \\
\hline Heparin & $78.4 \mathrm{USP} / 10 \mathrm{~mL}$ & 0.5 & 0.509 & -2.2 \\
EDTA & $20.0 \mu \mathrm{M}$ & 0.5 & 0.511 & -1.8 \\
Glucose & $0.35 \mathrm{mg} \mathrm{mL}$ & 0.509 & 1.6 \\
Histidine & $50 \mu \mathrm{M}$ & 0.5 & 0.492 & -3.2 \\
Albumin & $0.5 \mathrm{mg} \mathrm{mL}$ & 0.516 & 2.2 \\
Ascorbic acid & $20.0 \mu \mathrm{M}$ & 0.5 & 0.589 & -1.4 \\
Arginine & $50 \mu \mathrm{M}$ & 0.5 & 0.495 & 1 \\
Uric Acid & $50 \mu \mathrm{M}$ & 0.5 & 0.509 & -1.8 \\
Lysine & $50 \mu \mathrm{M}$ & 0.5 & & 1 \\
\hline
\end{tabular}

UV-dependent method is not precisely responsive. As a result, the usual difficulties of the UV-dependent method, including comparatively low selectivity and sensitivity, and disturbance of absorbance due to the evolution of gaseous oxygen, can be overcome.

The results summarized in Table 4 show that the linearity of the following method reaches about $12.75 \mathrm{U} \mathrm{mL}^{-1}$. The limit of quantification (LOQ) and limit of detection (LOD) of the method based on cobalt/bicarbonate reagent for catalase assessment were found to be 0.04 and $0.012 \mathrm{U} \mathrm{mL}^{-1}$, respectively.

Based on these results, the LOD and the linearity for the current method were better than those of other previously described methods [7-14], while the precision (within-run and between-run precision) and accuracy were identical. In terms of the methodology, this assay is preferable to estimate catalase activity compared with other biochemical methods.

The present method was utilized to measure catalase activity in liver and kidney tissue homogenates. The expected results were obtained, i.e., liver and kidney homogenates were generally shown to be associated with higher catalase activity than other tissues (Fig. 4), which may be due to the role of these organs in the detoxification of reactive oxygen species [25]. The catalase activity levels measured with the carbonato-cobaltate (III) complex method were compared with those obtained by the dichromate method as described previously by Sinha [7] and modified by Hadwan [8] (Fig. 4). The level of catalase activity of tissue homogenates measured with the new carbonato-cobaltate (III) complex method was

Table 2 The precision of the present method

\begin{tabular}{llll}
\hline & No. & Mean $\left( \pm\right.$ SD): $\mathrm{U} \mathrm{mL}^{-1}$ & CV \% \\
\hline Within-run & 20 & $6.4 \pm 0.19$ & $2.96 \%$ \\
Between-run & 20 & $6.6 \pm 0.26$ & $3.83 \%$ \\
\hline
\end{tabular}

SD standard deviation found to be compatible to that measured by the dichromate method.

In addition, the developed method could measure the catalase activity in bacteria. Two laboratory strains were used in the current study (Escherichia coli and Staphylococcus aureus). The levels of catalase activity of the studied bacteria obtained by using the proposed carbonato-cobaltate (III) complex method were found to be compatible with those obtained by the method reported previously by Iwase et al. [25]. Staphylococcus aureus was normally shown to exhibit higher catalase activity than Escherichia coli (Fig. 5).

\section{Conclusions}

This paper describes a simple method for assessing the activity of the catalase enzyme, which can be completed with only a few steps. This method allows the measurement of catalase enzyme activity in biological samples that contain high concentrations of vitamins, amino acids, proteins, antioxidants, or other interfering substances, as well as at low concentrations of hydrogen peroxide. The cobalt/bicarbonate solution is a sensitive reagent for hydrogen peroxide, which facilitates the assessment of catalase enzyme at low concentrations of substrate, confirming that the auto-inactivation of catalase is reduced during the assessment steps.

Table 3 Statistical examination of the results achieved for catalase activity by the dichromate and current methods $\left(\mathrm{U} \mathrm{mL}^{-1}\right)$

\begin{tabular}{ll}
\hline No. of experiments & 20 \\
\hline Mean of dichromate assay & 6.61 \\
Mean of the present assay & 6.45 \\
Mean of both assays & 6.53 \\
Regression coefficient B & 0.9972 \\
Regression coefficient A & 0.0028 \\
Correlation coefficient & 0.995 \\
\hline
\end{tabular}


Table 4 Analytical recovery of activity of catalase enzyme added to the reaction solution

\begin{tabular}{|c|c|c|c|c|}
\hline Catalase enzyme contents & $\begin{array}{l}\text { Catalase enzyme activity } \\
\text { added } \cup \mathrm{mL}^{-1}\end{array}$ & $\begin{array}{l}\text { Catalase enzyme calculated } \\
\text { activity } \cup \mathrm{mL}^{-1}\end{array}$ & $\begin{array}{l}\text { Catalase enzyme observed } \\
\text { activity }^{\mathrm{a}} \cup \mathrm{mL}^{-1}\end{array}$ & Recovery \% \\
\hline Enzymatic sample & - & - & 5 & - \\
\hline Enzymatic sample + catalase enzyme added & 1 & 6 & 5.85 & $97.5 \%$ \\
\hline Enzymatic sample + catalase enzyme added & 3 & 8 & 7.9 & $98.75 \%$ \\
\hline Enzymatic sample + catalase enzyme added & 5 & 10 & 9.82 & $98.2 \%$ \\
\hline Enzymatic sample + catalase enzyme added & 7 & 12 & 12.11 & $100.9 \%$ \\
\hline Enzymatic sample + catalase enzyme added & 8 & 13 & 12.75 & $98.2 \%$ \\
\hline Enzymatic sample + catalase enzyme added & 9 & 14 & 12.7 & $90.8 \%$ \\
\hline Enzymatic sample + catalase enzyme added & 10 & 15 & 12.75 & $85 \%$ \\
\hline
\end{tabular}

${ }^{a}$ mean of triplicate determinations

\section{Methods}

Principle

The current method is based on the concept of establishing a simple assay of catalase enzyme activity for biological tissues, which depends on the conversion of the oxidation state of cobalt (II) to cobalt (III) by hydrogen peroxide in the presence of bicarbonate solution. This process ends with the formation of a carbonato-cobaltate (III) complex $\left(\left[\mathrm{Co}\left(\mathrm{CO}_{3}\right)_{3}\right] \mathrm{Co}\right)$. This end product has two clear absorption peaks at 440 and $640 \mathrm{~nm}$. The 440-nm band has been used for the assessment of catalase activity. Dissociation of hydrogen peroxide is proportional to the activity of catalase enzyme in the used sample. The method has been developed for the measurement of catalase activity in biological samples (bacteria, red blood cells, and liver and kidney tissue homogenates).

\section{Chemicals}

The catalase enzyme was purchased from HiMedia Laboratories (New Delhi, India, product code: TC037). All other chemicals were provided from standard commercial suppliers and were of analytical grade.

\section{Reagents}

1. Cobalt (II) solution was prepared by dissolving $20.3 \mathrm{~g}$ of $\mathrm{Co}\left(\mathrm{NO}_{3}\right)_{2} \cdot 6 \mathrm{H}_{2} \mathrm{O}$ in $1 \mathrm{l}$ of distilled water.

2. Sodium hexametaphosphate solution (Graham salt) was prepared by dissolving $10 \mathrm{~g}$ of $\left(\mathrm{NaPO}_{3}\right)_{6}$ in $1 \mathrm{l}$ of distilled water.

3. Sodium bicarbonate solution was prepared by dissolving $180 \mathrm{~g}$ in 21 of double distilled water.

4. Working solution: This consisted of $100 \mathrm{ml}$ of cobalt (II) solution, $100 \mathrm{ml}$ of Graham salt solution, and $1800 \mathrm{ml}$ of sodium bicarbonate solution, which were mixed well after preparation (the order in which these substances are added is very important for obtaining accurate results).

5. Phosphate buffer ( $\mathrm{pH} 7.0,50 \mathrm{mM})$ was prepared by mixing the following solutions $(\mathrm{a} \& \mathrm{~b})$ at a ratio of 1:1.5 [(a) $6.81 \mathrm{~g}$ of $\mathrm{KH}_{2} \mathrm{PO}_{4}$ was dissolved in 11 of double distilled water and (b) $8.90 \mathrm{~g}$ of $\mathrm{Na}_{2} \mathrm{HPO}_{4} \cdot 2 \mathrm{H}_{2} \mathrm{O}$ was dissolved in $1 \mathrm{l}$ of double distilled water].

6. Hydrogen peroxide $(10 \mathrm{mM})$ was prepared by adding $0.1134 \mathrm{ml}$ of $30 \%$ hydrogen peroxide to

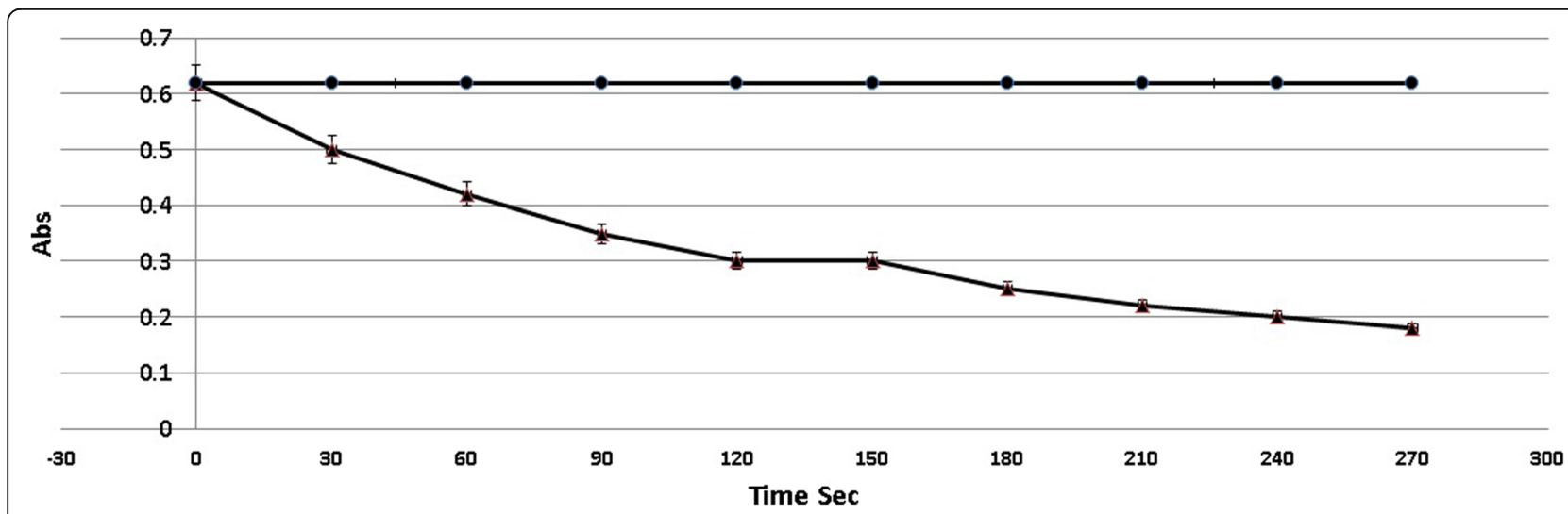

Fig. 2 The absorbance of carbonato-cobaltate(III) complex $\left(\left[\mathrm{Co}\left(\mathrm{CO}_{3}\right)_{3}\right] \mathrm{Co}\right)$ as a function of the incubation time of $\mathrm{H}_{2} \mathrm{O}_{2}$ alone $(\bullet)$ or $\mathrm{H}_{2} \mathrm{O}_{2}$ mixed with catalase enzyme $(0.86 \mathrm{U} \mathrm{mL}-1)(\mathbf{\Delta})$ 


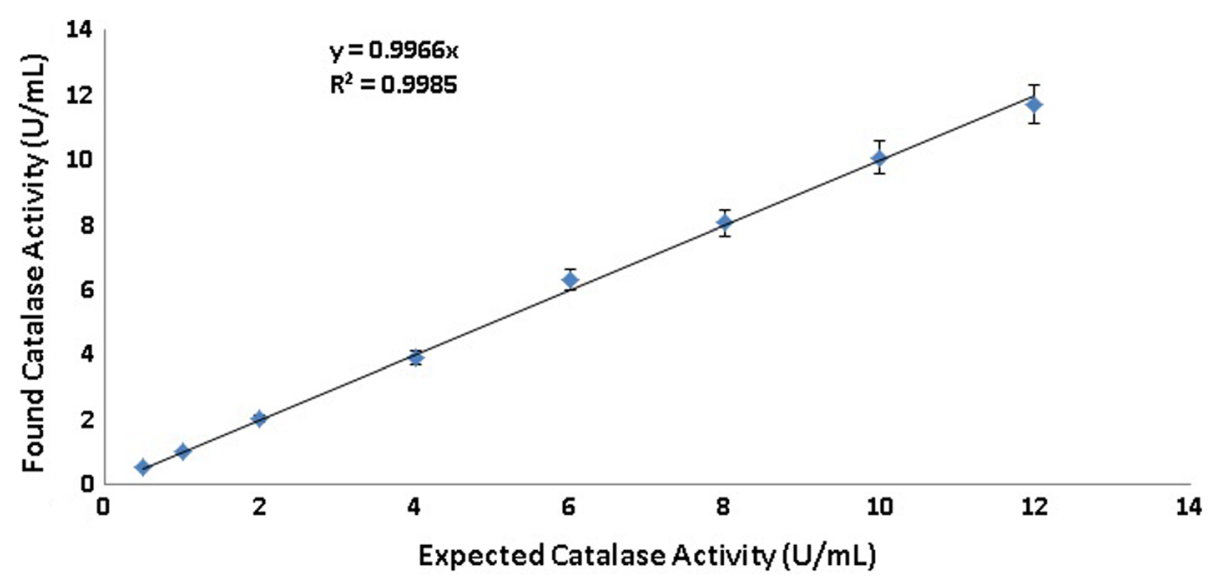

Fig. 3 The catalase activities measured by the carbonato-cobaltate(III) complex method versus those expected for red blood cell homogenate at different dilutions

$100 \mathrm{ml}$ of phosphate buffer; this solution was freshly prepared and calibrated daily depending on the molar extinction coefficient of hydrogen peroxide, which equals $43.6 \mathrm{M}^{-1} \mathrm{~cm}^{-1}$ at $240 \mathrm{~nm}$.

7. Erythrocyte lysate preparation: Three milliliters of whole blood was drawn from an anonymous donor by peripheral venous puncture. The whole blood was transferred into heparinized tubes to prevent coagulation. The centrifugation process was performed after $10 \mathrm{~min}$ at $400 \times \mathrm{g}$ for $10 \mathrm{~min}$, followed by separation and disposal of the plasma and buffy coat. The next step included washing $500 \mu \mathrm{l}$ of the remaining red blood cell sediment three times with $5 \mathrm{ml}$ of $0.9 \% \mathrm{NaCl}$ solution, with centrifugation at $400 \times \mathrm{g}$ for $10 \mathrm{~min}$ after each wash.
Subsequently, $2 \mathrm{ml}$ of ice-cold double distilled water was transferred into a test tube containing $500 \mu \mathrm{l}$ of erythrocyte sediment (fivefold dilution), vortexed for $5 \mathrm{~s}$, and incubated for $15 \mathrm{~min}$ at $4{ }^{\circ} \mathrm{C}$ in the dark. The final step included dilution of the resulting $2.5 \mathrm{ml}$ of fivefold re-suspended stock hemolysate with phosphate buffer solution $(0.05 \mathrm{M})$ to reach a dilution factor of 500. The resulting hemolysate solution was used as a source for catalase activity.

8. Tissue preparation: Male albino rats (100 g) were originally purchased from the animal house of the College of Science, University of Babylon, Iraq. Animals were housed in polypropylene cages under hygienic and standard environmental conditions $\left(28{ }^{\circ} \mathrm{C} \pm 2{ }^{\circ} \mathrm{C}\right.$, humidity $60-70 \%, 12 \mathrm{~h}$ light/dark

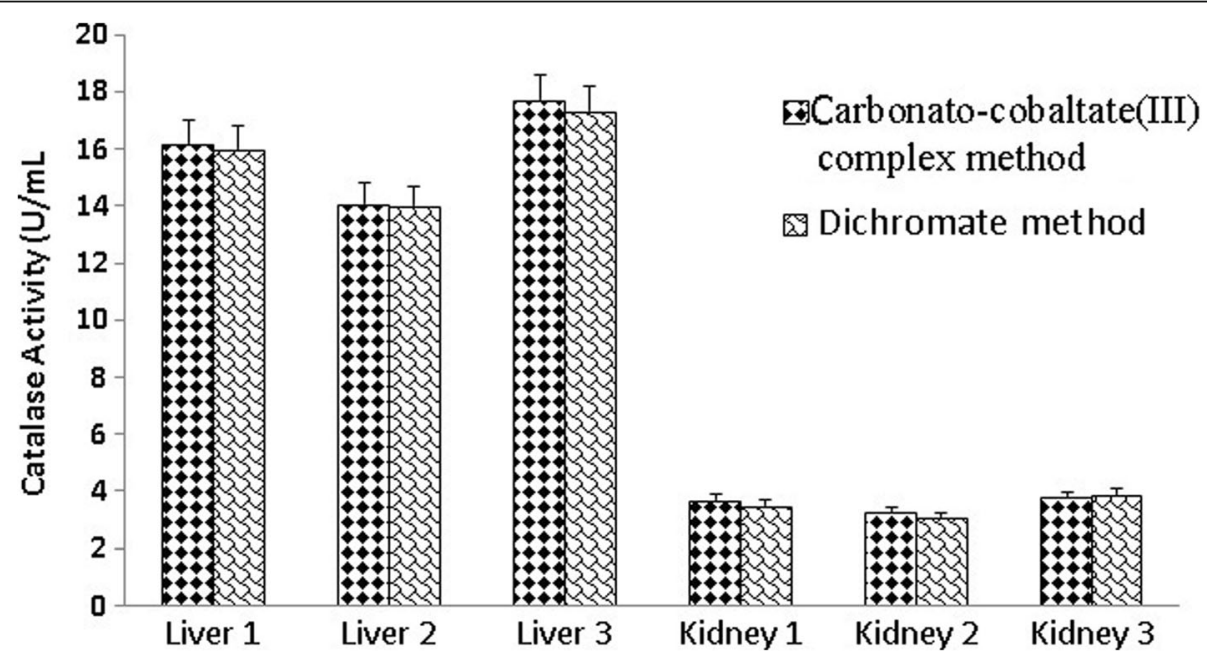

Fig. 4 The catalase activity of liver and kidney tissues homogenates measured with the carbonato-cobaltate(III) complex method in comparison to that with the dichromate method 


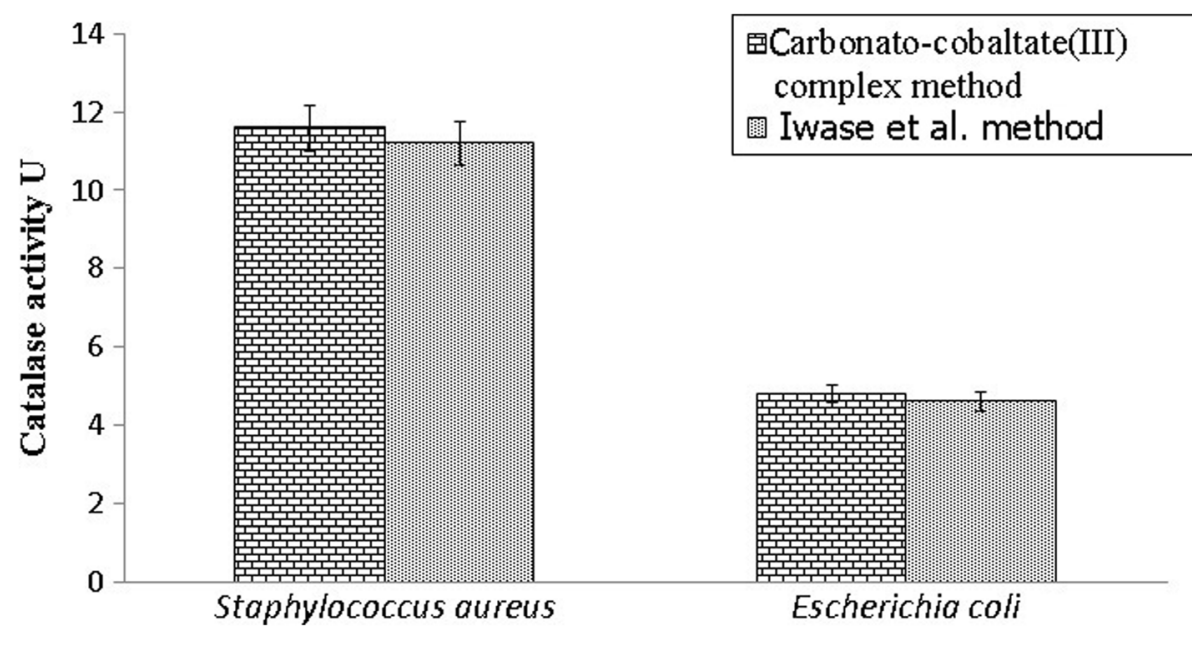

Fig. 5 The catalase activity of Escherichia coli and Staphylococcus aureus measured with the carbonato-cobaltate(III) complex method in comparison to that with the Iwase et al. [26]

cycle). The animals were allowed a diet and water ad libitum. Just before the tissue catalase activity measurements, the rats were anesthetized with IP sodium pentobarbital $(75 \mathrm{mg} / \mathrm{kg})$ and were sacrificed by open pneumothorax, and their kidney and liver tissues were surgically excised. Immediately after the surgery, a solution consisting of $0.9 \%(w / v) \mathrm{NaCl}$ was used to wash the tissue samples; this step eliminated external contaminants (blood, etc.). The next step included weighing and homogenizing the tissues using a cold $1.15 \%(\mathrm{w} / \mathrm{v})$ potassium chloride solution in a glass homogenizer. The homogenate solution was filtered and diluted (at a ratio of 1:500) with $0.05 \mathrm{M}$ phosphate buffer solution before analysis. The homogenates were immediately used for the assessment of catalase activity.

All clinical experiments that include human blood samples or animal tissues were approved by the Ethics Committee of the University of Babylon/College of Science (approval number A7/2017). All procedures

Table 5 The steps of the procedure used for assessing the activity of catalase

\begin{tabular}{llll}
\hline Reagents & Test & Standard & Blank \\
\hline Catalase source sample & $500 \mu \mathrm{l}$ & - & - \\
Distilled water & - & $500 \mu \mathrm{l}$ & $1500 \mu \mathrm{l}$ \\
Hydrogen peroxide & $1000 \mu \mathrm{l}$ & $1000 \mu \mathrm{l}$ & -
\end{tabular}

The tubes were mixed with a vortex and incubated at $37^{\circ} \mathrm{C}$ for $2 \mathrm{~min}$, after which the following substance was added:

Working solution $\quad 6000 \mu \mathrm{l} \quad 6000 \mu \mathrm{l} \quad 6000 \mu \mathrm{l}$

Next, the tubes were vortexed for $5 \mathrm{~s}$ and then kept at room temperature for $10 \mathrm{~min}$ in the dark. The changes in absorbance were recorded at $440 \mathrm{~nm}$ against the reagent blank and protocols were performed according to the Declaration of Helsinki. The signed written consent of the participant (41 years old) included in the study was obtained. Informed consent was obtained before beginning the study.

\section{Instrument:}

A spectrophotometer (Shimadzu 1800) was used in the current study.

\section{Procedure:}

As shown in Table 5.

\section{Calculation:}

The rate constant of a first-order reaction $(\mathrm{k})$ equation was used to determine catalase activity:

$$
\text { Catalase Activity of test } \mathrm{kU}=\frac{2.303^{*}}{\mathrm{t}} \log \frac{\mathrm{S}^{\circ}}{\mathrm{S}}
$$

t: time.

$S^{\circ}$ : absorbance of standard tube.

S: absorbance of test tube.

\section{Abbreviations}

$\left(\mathrm{H}_{2} \mathrm{O}_{2}\right)$ : hydrogen peroxide; $\left(\mathrm{NaPO}_{3}\right)_{6}$ : Sodium hexametaphosphate; Cat: catalase; $\mathrm{Co}\left(\mathrm{NO}_{3}\right)_{2} \cdot 6 \mathrm{H}_{2} \mathrm{O}$ : Cobalt (II) nitrate hexahydrate

\section{Acknowledgements}

We thank our colleagues in University of Babylon/College of Science for their technical support, comments, and help regarding our study, particularly Dr. Hussein O.M. Al-Dahmoshi, Dr. Noor S. K. Al-Khafaji, and Dr. Alaa Tariq.

Funding

This project was not financially supported by any party.

\section{Availability of data and materials}

The datasets used and/or analysed during the current study are available from the corresponding author on reasonable request. 


\section{Authors' contributions}

$\mathrm{MHH}$ carried out experiments, analyzed data and drafted the manuscript. The author read and approved the final manuscript.

\section{Ethics approval and consent to participate}

All clinical experiments that include human blood samples or animal tissues were approved by the Ethics Committee of the University of Babylon/ College of Science (approval number A7/2017). All procedures and protocols were performed according to the Declaration of Helsinki. The signed written consent of the participant included in the study was obtained. Informed consent has been obtained before beginning the study.

\section{Consent for publication}

Not applicable.

\section{Competing interests}

The authors declare that they have no competing interests with the contents of this paper.

\section{Publisher's Note}

Springer Nature remains neutral with regard to jurisdictional claims in published maps and institutional affiliations.

Received: 27 October 2017 Accepted: 30 July 2018

Published online: 03 August 2018

\section{References}

1. Olson KR, Gao Y, DeLeon ER, Arif M, Arif F, Arora N, et al. Catalase as a sulfide-sulfur oxido-reductase: an ancient (and modern?) regulator of reactive sulfur species (RSS). Redox Biol. 2017;12:325-39.

2. Van Lente F, Pepoy M. Coupled-enzyme determination of catalase activity in erythrocytes. Clin Chem. 1990;36:1339-43.

3. Jenkins RR. Catalase activity in skeletal muscle of varying fiber types. Cell Mol Life Sci. 1981;37:67-8.

4. Switala J, Loewen PC. Diversity of properties among catalases. Arch Biochem Biophys. 2002;401:145-54.

5. Vendemiale G, Grattagliano I, Altomare E. An update on the role of free radicals and antioxidant defense in human disease. Int J Clin Lab Res. 1999;29:49-55.

6. Wang Gl, Fung DY. Feasibility of using catalase activity as an index of microbial loads on chicken surfaces. J Food Sci. 1986;51:1442-4.

7. Sinha AK. Colorimetric assay of catalase. Anal Biochem. 1972:47:389-39494.

8. Hadwan MH. New method for assessment of serum catalase activity. Indian J Sci Technol. 2016;9:1-5

9. Hadwan MH, Abed HN. Data supporting the spectrophotometric method for the estimation of catalase activity. Data in brief. 2016;6:194-9.

10. Cohen $G$, Dembiec D, Marcus J. Measurement of catalase activity in tissue extracts. Anal Biochem. 1970;34:30-8.

11. Johansson LH, Borg LH. A spectrophotometric method for determination of catalase activity in small tissue samples. Anal Biochem. 1988;174:331-6.

12. Wheeler CR, Salzman JA, Elsayed NM, Omaye ST, Korte DW. Automated assays for superoxide dismutase, catalase, glutathione peroxidase, and glutathione reductase activity. Anal Biochem. 1990;184:193-9.

13. Chance B, Maehly AC. [136] Assay of catalases and peroxidases Methods Enzymol 1955;2:764-775.

14. Mueller S, Riedel HD, Stremmel W. Determination of catalase activity at physiological hydrogen peroxide concentrations. Anal Biochem. 1997:245:55-60.

15. Rørth M, Jensen PK. Determination of catalase activity by means of the Clark oxygen electrode. Biochim Biophys Acta. 1967;139:171-3.

16. Luís A, Ortega MG, Lopez AL, Gorge JL. A more sensitive modification of the catalase assay with the Clark oxygen electrode: application to the kinetic study of the pea leaf enzyme. Anal Biochem. 1977;80:409-15.

17. Cohen G, Kim M, Ogwu V. A modified catalase assay suitable for a plate reader and for the analysis of brain cell cultures. J Neurosci Methods. 1996;67:53-6

18. Aebi H. [13] Catalase in vitro. Methods Enzymol. 1984;105:121-6.

19. Richardson M, Huddleson IF, Bethea R. Study of catalase in erythrocytes and bacteria. I. Procedure for the determination of the catalase activity of erythrocytes. Arch Biochem Biophys. 1953;42:114-23.
20. Kroll RG, Frears ER, Bayliss A. An oxygen electrode-based assay of catalase activity as a rapid method for estimating the bacterial content of foods. J Appl Microbiol. 1989;66:209-17.

21. Guwy AJ, Martin SR, Hawkes FR, Hawkes DL. Catalase activity measurements in suspended aerobic biomass and soil samples. Enzym Microb Technol. 1999;25:669-76.

22. Euler HV, Josephson K. Über katalase. I European J Org Chem. 1927;452:158-81.

23. Goldblith SA, Proctor BE. Photometric determination of catalase activity. J Biol Chem. 1950:187:705-9.

24. Masschelein W, Denis M, Ledent R. Spectrophotometric determination of residual hydrogen peroxide. Water Sewage Works. 1977;8:69-72.

25. Sarkar S, Mukherjee S, Chattopadhyay A, Bhattacharya S. Differential modulation of cellular antioxidant status in zebrafish liver and kidney exposed to low dose arsenic trioxide. Ecotoxicol Environ Saf. 2017;135:173-82.

26. Iwase T, Tajima A, Sugimoto S, Okuda Kl, Hironaka I, Kamata Y, et al. A simple assay for measuring catalase activity: a visual approach. Sci Rep. 2013:3:3081.

\section{Ready to submit your research? Choose BMC and benefit from:}

- fast, convenient online submission

- thorough peer review by experienced researchers in your field

- rapid publication on acceptance

- support for research data, including large and complex data types

- gold Open Access which fosters wider collaboration and increased citations

- maximum visibility for your research: over $100 \mathrm{M}$ website views per year

At BMC, research is always in progress.

Learn more biomedcentral.com/submission 